\title{
Distribution and Predominance of Genotype 3 in Hepatitis C Virus Carriers in the Province of Kahramanmaras, Turkey
}

\author{
Ahmet Caliskan ${ }^{1,}$; Ozlem Kirisci ${ }^{1}$; Esra Ozkaya ${ }^{1}$; Sevinc Ozden ${ }^{1}$; Seray Tumer ${ }^{1}$; Serkan Caglar ${ }^{2}$; \\ Selma Ates Guler ${ }^{3}$; Hande Senol $^{4}$ \\ ${ }^{1}$ Department of Medical Microbiology, Necip Fazil City Hospital, Kahramanmaras, Turkey \\ ${ }_{2}^{2}$ Department of Medical Biohemistry, Necip Fazıl City Hospital, Kahramanmaras, Turkey \\ ${ }^{3}$ Department of Infectious Diseases and Clinical Microbiology, Faculty of Medicine, Sutcu Imam University, Kahramanmaras, Turkey \\ ${ }^{4}$ Department of Biostatistics, Faculty of Medicine, Pamukkale University, Denizli, Turkey \\ ${ }^{*}$ Corresponding Author: Ahmet Caliskan, Medical Microbiology Laboratory, Necip Fazil City Hospital, Kahramanmaras, Turkey. Tel: +90-3442282800, E-mail: ahmetsuna@msn.com
}

Received: November 5, 2014; Revised: March 2, 2015; Accepted: April 2, 2015

\begin{abstract}
Background: The hepatitis C virus (HCV) has six major genotypes and more than 100 subtypes, and the determination of the responsible genotype, collection of epidemiological data, tailoring antiviral therapy, and prediction of prognosis have an important place in disease management.

Objectives: The aim of the present study was to determine the distribution of HCV genotypes across geographic regions and compare these data with those obtained from other geographic locations.

Patients and Methods: The HCV genotypes were identified in HCV RNA positive blood samples, obtained from different centers. The HCV genotype was determined using molecular methods [Real-Time Polymerase Chain Reaction(RT-PCR)] in 313 patients, who were found to be positive for HCVRNA. The presence of HCVRNA was investigated using the RT-PCR method in serum samples delivered to the Microbiology Laboratory at Kahramanmaras Necip Fazll City Hospital, Kahramanmaras, Turkey, from the centers located in Kahramanmaras City center and peripheral districts of the province, between March 2010 and August 2014. The HCV genotype analysis was performed in HCV RNA positive samples, using RT-PCR reagents kit. Urine samples from the patients were tested for amphetamine with an Amphetamines II (AMPS2) kit, cocaine was tested with a Cocaine II (COC2) kit, opiates were tested with an Opiates II(OPI2) kit, and cannabinoids were tested with a Cannabinoids II (THC2) kit in Roche/Hitachi Cobas c501 device.

Results: The blood samples collected from 313 patients were included in the study. Of these patients, 212 (67.7\%) were male and 101 (32.3\%) were female. The mean age of the patients was $41.29 \pm 20.32$ years. In terms of HCV genotype distribution, 162 patients (51.7\%) had genotype 1,144 patients $(46 \%$ ) had genotype 3 , four patients (1.3\%) had genotype 2 , and three patients $(1 \%)$ had genotype 4 . The results of urine drug tests were available in only 65 patients (20.2\%). Of these, 61(93.8\%) patients had HCV genotype 3.

Conclusions: In conclusion, the prevalence of HCV genotype 1 was 51.7\%, which was lower than the rates reported in other studies in Turkey, while the prevalence of HCV genotype 3 was $46 \%$, which was remarkably higher than the reported Turkish data. In addition, the prevalence rate for genotype 3 reported in the present study is the highest that has ever been reported in the literature.
\end{abstract}

Keywords: Hepatitis C; Genotype; Real-Time Polymerase Chain Reaction; Turkey

\section{Background}

It is estimated that approximately $170-300$ million people worldwide are infected with the hepatitis $C$ virus (HCV). The HCV accounts for $20 \%$ of all cases with acute viral hepatitis and $70 \%$ of all cases with chronic viral hepatitis (1). The infection with HCV is associated with high morbidity and mortality, due to the development of cirrhosis and hepatocellular carcinoma, and approximately 350000 people die every year, globally, due to HCV infection (2). The frequencies of HCV genotypes in different geographic regions change over time, depending on the study population, the route of infection, and virus mutation. The HCV genotype $1 \mathrm{~b}$ is the predominant subtype in Turkey, Russia, Moldova, and Uzbekistan, while genotype 4 is predominant in Saudi Arabia, Iraq, Qatar, Bahrain, Kuwait, and Yemen, and genotype $6 a$ is predominant in Chi- na. The HCV genotype 3a is predominant in Pakistan and India. The HCV genotype 1a is the predominant subtype in Iran, despite a high number of visitors from and to Arab countries, in which genotype 4 has been identified as the predominant subtype, and also the fact that Iran has a border with Tajikistan and Turkmenistan in the north, in which genotype $1 \mathrm{~b}$ appears as the major subtype (3). Gene sequencing studies identified six major genotypes and more than 100 subtypes of $\operatorname{HCV}(4,5)$. The HCV genotypes 1, 2, and 3 are the most commonly observed genotypes worldwide (6). The HCV genotype $1 \mathrm{~b}$ is the most common genotype detected in HCV-infected patients in Turkey $(6,7)$. The identification of genotypes, prior to therapy, is particularly important, due to the fact that therapies may vary depending on the genotypes involved

Copyright (C) 2015, Kowsar Corp. This is an open-access article distributed under the terms of the Creative Commons Attribution-NonCommercial 4.0 International License (http://creativecommons.org/licenses/by-nc/4.0/) which permits copy and redistribute the material just in noncommercial usages, provided the original work is properly cited. 
$(2,3)$. The distribution of the HCV genotype exhibits geographic variations around the world, and the knowledge of the distribution of genotypes in a particular country, as well as in a particular region of the country, are essential for tailoring appropriate treatment strategies (8). The studies conducted in Turkey identified HCV genotype 1 as the predominant subtype, and the studies reported a lower frequency for genotype 3. The genotypes identified in Turkey do not exhibit age and gender difference. In contrast to previous reports, the present study showed a prevalence rate for genotype 1 below the average of Turkish data and a prevalence rate for genotype 3 above the average of Turkish data.

\section{Objectives}

The aim of the present study was to determine the distribution of HCV genotypes across geographic regions and compare these data with those obtained from other geographic locations.

\section{Patients and Methods}

\subsection{Sample Selection}

The province of Kahramanmaras is divided into nine districts, with a total population of 1000000 . The study hospital is a state hospital and the largest central hospital in the province. Between March 2010 and August 2014, the study included samples from the general population and subjects with the suspicion of illicit drug use, who are placed on probation, during which they are subjected to regular urine drug testing, as mandated by the prosecution office, under the supervision of a psychiatrist, for the purpose of resettlement. At our hospital, HCV RNA and HCV genotypes are regularly tested in samples from HCV-positive patients from the general population and subjects on probation delivered from the city center and nine districts of the province. Accordingly, the presence of HCV RNA was investigated in 2736 samples from antiHCV positive patients. An HCV genotype analysis was performed in 313 patients with HCV-RNA positivity. The local ethics committee approved the study with an issue number 3, dated May 26, 2015. Informed consent was obtained from the patients who underwent urine drug testing.

\subsection{Hepatitis C Virus RNA Analysis}

The sera separated from the blood samples dispatched to our laboratory, with the diagnosis of $\mathrm{HCV}$, were stored at $-80^{\circ} \mathrm{C}$ until analysis. The samples were warmed to room temperature before analysis. Viral DNA was extracted using a commercial extraction kit (QIAsymphony DSP Virus/Pathogen Midi Kit, QIAGEN, Hilden, Germany). Quantification of HCV RNA was performed using ArtusHCV QS-RG Q Kit (QIAGEN, Hilden, Germany) and the real-time polymerase chain reaction (RT-PCR) method in the RotorGene RG-Q (QIAGEN, Hilden, Germany) device.

\subsection{Genotyping in HCV RNA Positive Serum Sam- ples}

The HCV genotype was tested using the RT-PCR method as per the manufacturer's instruction. Genotypes 1/2/3/4 were analyzed. Genotyping was performed in serum samples obtained from 313 patients that were found to be positive for HCV-RNA. The sera were stored at $-80^{\circ} \mathrm{C}$, until the day of analysis. The samples were warmed to room temperature before analysis. The HCV genotype analysis was performed using GenoSen's HCV Genotyping 1/2/3/4 RT-PCR Reagents Kit (Genome Diagnostics, New Delhi, India). For each reaction, 7.5 $\mu$ L HCV Genotyping Super Mix (R1) were mixed with $2.5 \mu \mathrm{L}$ of HCV Genotyping Mg solution (R2) and $15 \mu \mathrm{L}$ of patient serum. After 10 minutes of a single cycle at $95^{\circ} \mathrm{C}$ in the Rotor-RG-Q (QIAGEN, Hilden, Germany), 45 cycles were completed ( $15 \mathrm{sec}$ at $95^{\circ} \mathrm{C}, 20$ seconds at $55^{\circ} \mathrm{C}$, and 15 seconds at $72^{\circ} \mathrm{C}$ ).

\subsection{Urine Drug Test}

The presence of amphetamines (i.e. captagon, Ritalin, Dexedrine, and ecstasy), cocaine, opiates (i.e. morphine, codeine, heroin, oxycodone, fentanyl, and methadone) and cannabinoids (THC and cannabis) were investigated in urine samples from patients who were on supervised release. All these tests were performed using Roche/Hitachi Cobas c501 device (Roche/Hitachi, Indianapolis, IN, USA). Amphetamine was tested with an Amphetamines II (AMPS2) kit, cocaine was tested with a Cocaine II (COC2) kit, opiates were tested with an Opiates II (OPI2) kit, and cannabinoids were tested with a Cannabinoids II (THC2) kit $(9,10)$.

\section{Results}

Between March 2010 and May 2014, HCV genotype analysis was performed on a group of 313 patients, which included 212 males (67.7\%) and 101 females (32.2\%). The mean age of the patients was $41.29 \pm 20.32$ years. The HCV genotype 1 favored female gender, affecting $56.7 \%$ of women, with a mean age of 60.4 years. The HCV genotype 3 favored the male gender, affecting $95.8 \%$ of men, and the mean age was 25 years. The age distribution and mean age, according to the genotypes, are presented in Table 1. The mean viral load was $1.6 \times 10^{6} \mathrm{IU} / \mathrm{mL}$, for genotype 1 , and $2.1 \times 10^{6} \mathrm{IU} / \mathrm{mL}$, for genotype 3 . The mean HCV RNA load of the patients was $1.9 \times 10^{6} \mathrm{IU} / \mathrm{mL}$. In terms of HCV genotype distribution, 162 patients (51.7\%) had genotype 1,144 patients ( $46 \%$ ) had genotype 3 , four patients $(1.3 \%)$ had genotype 2 , and three patients (1\%) had genotype 4 . As depicted in Figure 1, the prevalence of genotype 1 declined and the prevalence of genotype 3 increased over the years. The individuals convicted of illicit drug offenses in Turkey are placed on probation, during which they are subjected to urine drug testing every 3 weeks, as mandated by the prosecution office, under the supervision of police, after providing consent for the test. After the ret- 
rospective review of 313 patients, the results of urine drug tests were available in only $65(20.2 \%)$ patients, 61 (93.8\%) of which had HCV genotype 3. Other data regarding the patients, except age, gender, and place of origin, could not be obtained. Of patients possessing a risk factor, only 65 had a positive history for illicit drug use.

\section{Discussion}

The HCV genotyping has an important role in the selection of appropriate therapy, duration of treatment, and close monitoring of the response to therapy, in patients with chronic hepatitis $\mathrm{C}$ infection. The response to interferon therapy, in patients infected with HCV genotypes 1 and 4 , is poorer and the duration of treatment is longer, compared to patients infected with genotypes 2 and 3. In addition, patients infected with genotype $1 \mathrm{~b}$ have been reported to have a higher risk of developing hepatocellular carcinoma. The HCV genotyping, besides shaping the treatment, also provides information regarding the prognosis of the patients (8). Of the 313 patients who were found to be positive for HCV RNA, 67.7\% were males, who were significantly predominant among these patients $(\mathrm{P}=0.0001)$. Although other studies conducted in Turkey and Pakistan showed no significant difference in terms of gender, the results of the present study showed male predominance, which was parallel to the findings of a study conducted in Iran (79.6\%) (11-13). When genotype distribution was evaluated in terms of gender, genotype 3 showed $95.8 \%$ male predominance and type 1 showed $56.7 \%$ female predominance. The mean age of the patients in our study was $41.29 \pm 20.32$ years. This result was consistent with the findings of Hadinedoushan et al. (13), who reported an age range of 21 - 31 years for genotype 1a and the predominance of genotype 3 in all age groups, beyond this age group. The mean age was 55 years in 161 patients with genotype 1 . This finding was consistent with the finding of Buruk et al. (11). When the mean age was analyzed separately for each year, the mean age for type 1 was 48 years in 2010, 54 years in 2011, 60 years in 2012, 60 years in 2013, and 62 years in 2014. There was an increase in the mean age, between 2010 and 2014. The mean age was 25 years in 138 patients with genotype 3. There was an increase in the mean age for type 3, when it was analyzed separately for each year. The mean viral load for HCV RNA was $1.9 \times 10^{6} \mathrm{IU} / \mathrm{mL}$. There was no significant correlation between viral load for HCV RNA and HCV genotype. Likewise, Hadinedoushan et al. (13) did not report any relationship between viral load and genotype. The genotype distribution pattern in Turkey shows the predominance of genotype 1 (57.6 -100\%). In general, genotype 1 is more common in the interior regions and it is reported to be less common in large cities and in those allowing the flow of immigrants (7, 11, 14-24). The studies related to HCV genotype distribution in Turkey are presented in Table 2 Figure 2.

\begin{tabular}{|c|c|c|c|c|}
\hline \multirow[t]{2}{*}{ Genotype } & \multicolumn{2}{|c|}{ Sample Size } & \multicolumn{2}{|c|}{ Mean Age, $y$} \\
\hline & Female & Male & Female & Male \\
\hline 1 & $92(56.7)$ & $70(43.2)$ & 60.44 & 51.43 \\
\hline 2 & - & $4(100)$ & - & 40 \\
\hline 3 & $6(4.2)$ & $138(95.8)$ & 31.4 & 25 \\
\hline 4 & $2(66.6)$ & $1(33.3)$ & 24 & 25 \\
\hline
\end{tabular}

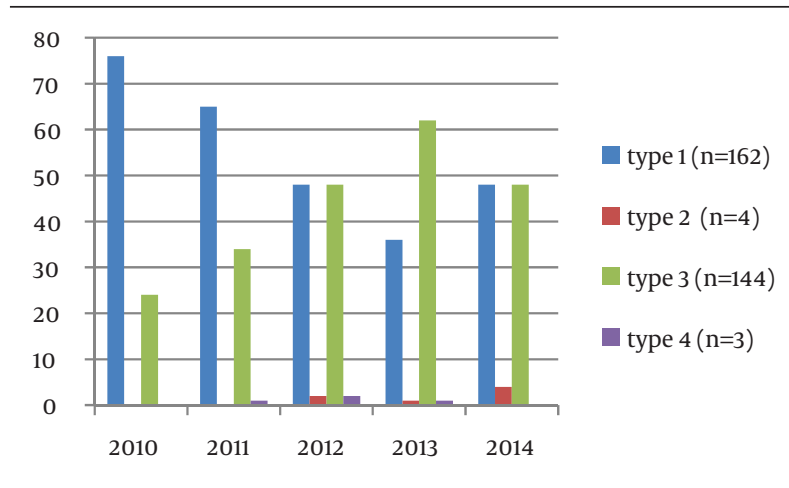

Figure 1. The Percent Distribution of Genotype Over the Years

\begin{tabular}{lccccccc}
\hline Table 2. The Studies Related to HCV Genotype Distribution in Turkey & \multicolumn{7}{c}{} \\
\hline
\end{tabular}




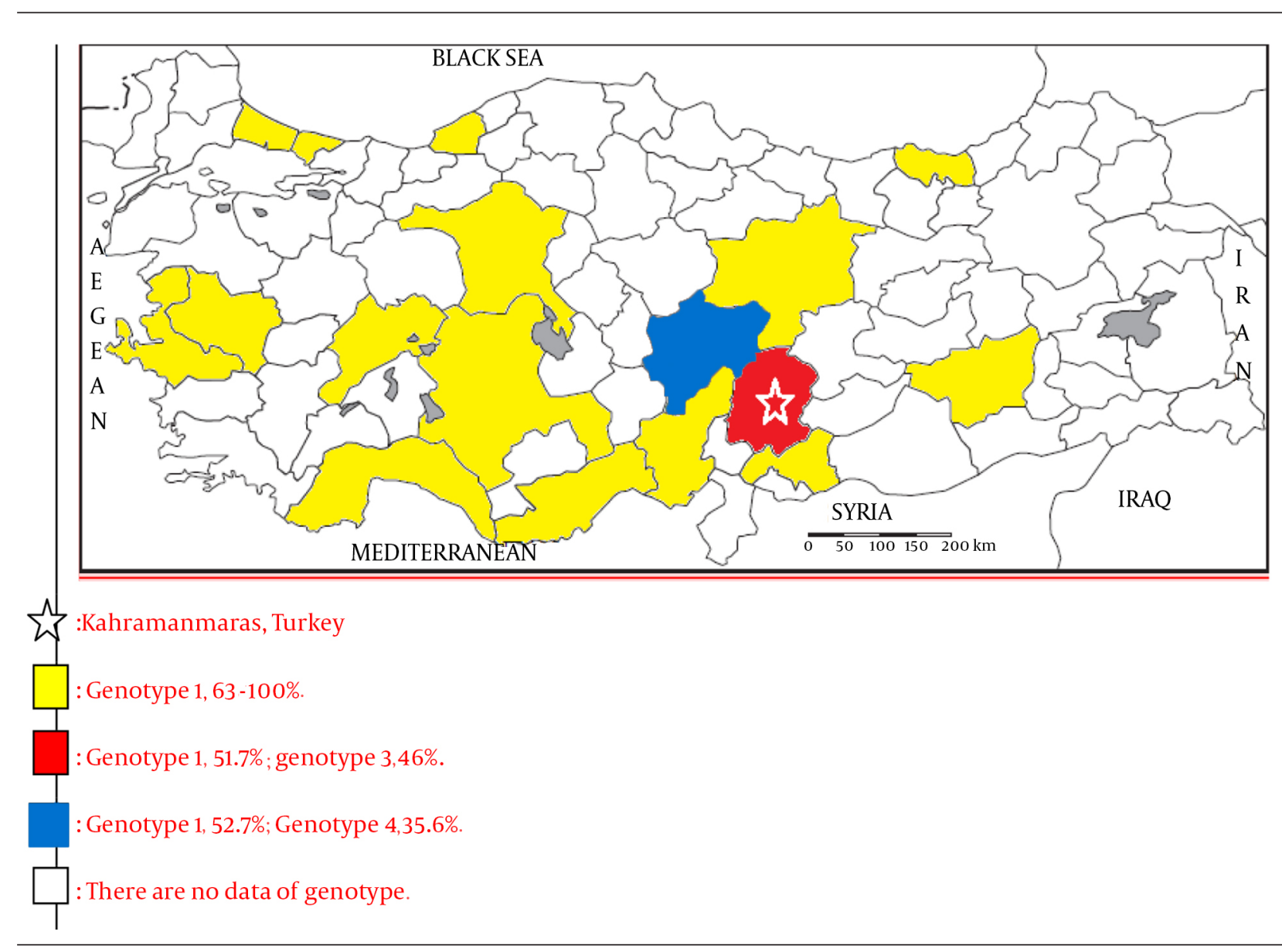

Figure 2. Current Data of HCV Genotype Distribution Geographical map of the Cities in Turkey

In the present study that was conducted in the province of Kahramanmaras, which has a population of 1 million people and is located in the Mediterranean region, the prevalence of genotype 1 was $51.7 \%$ and the prevalence of genotype 3 was $46 \%$, which differed from the country data. Consistent with the data from other regions in Turkey, the prevalence of genotype 2 was $1.3 \%$ in the present study. High prevalence rates have been reported for genotype 4, which is mostly reported in the Middle East, in Kayseri and Afyon provinces, in Turkey $(21,25)$. The prevalence of genotype 4 was found to be $1 \%$ in the present study, which is consistent with other studies. The analysis of yearly distribution revealed interesting findings. Genotype 1 was the predominant type in years 2010 and 2011 (76\% and 65\%, respectively), and this rate declined to $36 \%$ and lost its predominance in 2012. The HCV genotype 3 has a low countrywide prevalence in Turkey $(1-3 \%)(7,11,14,16-19,21-23)$. The highest prevalence rate was reported by Kucukoztas et al. (17), as 9.6\%. Different from the other studies reported in other regions, the prevalence of HCV genotype 3 was $46 \%$, which was a very high prevalence rate that has not been previously reported. When the study data were analyzed separately for each individual year, the $76 \%$ prevalence rate for genotype 1 in 2010 declined to $36 \%$ in 2013 , and, in contrast, the $24 \%$ prevalence rate for genotype 3 in 2010 increased to $62 \%$ in 2013 and become the predominant genotype. We suggest that intravenous drug use may have become more common among young males, and this may have led to an increase in the prevalence of genotype 3 in Kahramanmaras City. However, further studies are required to confirm the increase in the prevalence. Genotype distribution across years is presented in Figure 2. It can be argued that genotype 3 in the southern region of Turkey is becoming more prevalent, when compared to the prevalence rate in other regions. The response to therapy is better in genotype 3, when compared to genotype 1 ; however, genotype 3 has clinical significance due to its association with hepatosteatosis and accelerated liver fibrosis, in the case of chronic disease, and early therapy is essential for better prognosis (8). We consider that further studies must be conducted to determine the causes for increasing prevalence of genotype 3 in the southern region of Turkey, which is different from the other regions. In the Turkish justice system, those who are arrested or sentenced to prison for the crimes they have committed 
Caliskan A et al.

Table 3. Distribution of HCV Genotypes and Illicit Drugs Detected in Patients who Have Been Placed on Probation

\begin{tabular}{|c|c|c|c|c|}
\hline Drugs & Type 1 & Type 2 & Type 3 & Type 4 \\
\hline Opiates positive, iv & 1 & - & 24 & - \\
\hline Cannabinoids/Amphetamines/Cocaine positive, oral & 1 & - & 12 & - \\
\hline History of opiates use, iv & - & - & 15 & - \\
\hline History of Cannabinoids/Amphetamines/Cocaine use, oral & 1 & - & 10 & 1 \\
\hline Total & 3 & & 61 & 1 \\
\hline
\end{tabular}

can be placed on supervised release within the community, under which the parolee is considered to be serving his/her sentence under custody and supervision, instead of serving prison sentence. In this scope, individuals who are convicted of illicit drug offenses are subjected to urine drug testing every 3 weeks, by the prosecution office, under the supervision of the police, after providing consent (26). Genotype 3 is more common among intravenous drug users and young people (27-31). Based on these data, 313 patients were retrospectively reviewed for the availability of urine drug testing in the scope of supervised release, to investigate the reasons for increased prevalence of genotype 3, which became the predominant type over years. The results of urine drug tests were available in only 65 patients (20.2\%). As explained in Table 3 in detail, 61 of 65 patients (93.8\%) had HCV genotype 3. The mean age of the patients with HCV genotype 3 was 25 years and the fact that $95.8 \%$ of these patients were males suggested that other patients, for whom urine drug tests were not available, were also illicit drug users. However, this presumption requires support from further comprehensive studies.

The HCV genotypes show different distribution patterns in different parts of the world (32-35). Attaullah et al. (12) examined genotype distribution in $28400 \mathrm{HCV}$-infected individuals studied in 34 different trials in Pakistan, and reported a prevalence rate of 78.96\% for genotype 3, 7.03\% for genotype $1,3.81 \%$ for genotype $2,1.59 \%$ for genotype 4 , $0.10 \%$ for genotype $5,0.13 \%$ for genotype 6 , and $5.03 \%$ for mixed genotypes. Furthermore, they did not report differences between HCV genotypes, in terms of age and gender. Other studies have also reported findings supporting these results (36-38). However, the studies in the US and Asia reported that genotype 3 was associated with young age, particularly with intravenous drug users, tattooing, and piercing. Outbreaks have been reported among intravenous drug users, as a result of shared use of injectors and needles (27-31, 37). Hadinedoushan et al. (13) reported a prevalence rate of 50\% for HCV genotype 3, 38\% for genotype $1 \mathrm{a}, 6.8 \%$ for genotype $1 \mathrm{~b}$, and $1.6 \%$ for genotype 2. Zhang et al. (39) studied HCV-infected intravenous drug users in China and reported a prevalence rate of $47 \%$ for genotype 6 and $41 \%$ for genotype 3. Sanders-Buell et al. (40) reported a prevalence rate of $62 \%$ for genotype 3 and $35 \%$ for genotype 1 among HCV-infected intravenous drug users in Afghanistan. The limitation of the present study was that urine drug tests were conducted on only 65 of the 313 patients.
In conclusion, the present study revealed data regarding the distribution of HCV genotypes over a period of 4 years in the province of Kahramanmaras, which is located in the southern part of Turkey. The main difference of the present study from other reports in Turkey is that the prevalence of HCV genotype 1 declined and the prevalence of HCV genotype 3 increased over the years in Turkey, to become the predominant genotype, and the prevalence rate for genotype 3 is the highest rate ever reported for this genotype in the literature.

\section{Authors' Contributions}

Study concept and design: Ahmet Caliskan, Acquisition of data: Ahmet Caliskan, Ozlem Kirisci, Esra Ozkaya, Serkan Caglar, Analysis and interpretation of data: Ahmet Caliskan, Ozlem Kirisci, Esra Ozkaya, Serkan Caglar, Seray Tumer, Drafting of the manuscript: Ahmet Caliskan, Ozlem Kirisci, Esra Ozkaya, Critical revision of the manuscript for important intellectual content: Ahmet Caliskan, Ozlem Kirisci, Esra Ozkaya, Sevinc Ozden, Selma Ates Guler, Statistical analysis: Hande Senol.

\section{References}

1. Koff RS. Hepatitis C. In: Gorbach SL, Bartlett JG, Blacklow NR editors. Infectious Diseases.. Philadelphia: Lippincott Williams; 2004.

2. Khan N, Akmal M, Hayat M, Umar M, Ullah A, Ahmed I, et al. Geographic distribution of hepatitis $C$ virus genotypes in pakistan. Hepat Mon. 2014;14(10).

3. Khodabandehloo M, Roshani D. Prevalence of hepatitis C virus genotypes in Iranian patients: a systematic review and metaanalysis. Hepat Mon. 2014;14(12).

4. Davis GL. Hepatitis C genotypesandquasispecies. Am J Med. 1999;107(6):21-6.

5. Forns X, Bukh J. THE MOLECULAR BIOLOGY OF HEPATITIS C VIRUS : Genotypes and Quasispecies. Clin Liver Dis. 1999;3(4):693-716.

6. Bokharaei-Salim F, Keyvani H, Monavari SH, Alavian SM, Fakhim S, Nasseri S. Distribution of hepatitis C virus genotypes among azerbaijani patients in capital city of iran-tehran. Hepat Mon. 2013;13(9).

7. Altuglu I, Soyler I, Ozacar T, Erensoy S. Distribution of hepatitis C virus genotypes in patients with chronic hepatitis $C$ infection in Western Turkey. Int J Infect Dis. 200 8;12(3):239-44.

8. Cekin Y, Gur N, Cekin AH, Altuglu I, Yazan Sertoz R. [Investigation of hepatitis $C$ virus genotype distribution in patients with chronic hepatitis $C$ infections in Antalya Training and Research Hospital, Turkey]. Mikrobiyol Bul. 2014;48(3):484-90.

9. Armbruster DA, Schwarzhoff RH, Pierce BL, Hubster EC. Method comparison of EMIT II and online with RIA for drug screening. $J$ Forensic Sci.1993;38(6):1326-41.

10. Armbruster DA, Schwarzhoff RH, Hubster EC, Liserio MK. Enzyme immunoassay, kinetic microparticle immunoassay, radioimmunoassay, and fluorescence polarization immunoassay compared for drugs-of-abuse screening. Clin Chem. 1993;39(10):2137-46. 
11. Buruk CK, Bayramoglu G, Reis A, Kaklikkaya N, Tosun I, Aydin F. [Determination of hepatitis $C$ virus genotypes among hepatitis C patients in Eastern Black Sea Region, Turkey]. Mikrobiyol Bul. 2013;47(4):650-7.

12. Attaullah S, Khan S, Ali I. Hepatitis C virus genotypes in Pakistan: a systemic review. Virol J. 2011;8:433.

13. Hadinedoushan H, Salmanroghani H, Amirbaigy MK, AkhondiMeybodi M. Hepatitis C virus genotypes and association with viral load in yazd, central province of iran. Hepat Mon. 2014;14(3).

14. Bozdayi AM, Aslan N, Bozdayi G, Turkyilmaz AR, Sengezer T, Wend $\mathrm{U}$, et al. Molecular epidemiology of hepatitis B, C and D viruses in Turkish patients. Arch Virol. 2004;149(11):2115-29.

15. Selcuk H, Kanbay M, Korkmaz M, Gur G, Akcay A, Arslan H, et al. Distribution of HCV genotypes in patients with end-stage renal disease according to type of dialysis treatment. Dig Dis Sci. 2006;51(8):1420-5.

16. Sanlidag T, Akcali S, Ozbakkaloglu B, Ertekin D, Akduman E. [Distribution of hepatitis $C$ virus genotypes in Manisa region, Turkey]. Mikrobiyol Bul.2009;43(4):613-8.

17. Kucukoztas MF, Ozgunes N, Yazici S. [Investigation of the relationship between hepatitis c virus (HCV) genotypes with HCVRNA and alanine aminotransferase levels in chronic hepatitis c patients]. Mikrobiyol Bul.2010;44(1):111-5.

18. Celik C, Bakıcı MZ, Kaygusuz R, Erturk R. The Searching of HCV Genotyping Distributions in the Region of Sivas. Viral Hepatit Derg. 2010;16:106-10.

19. Karsligil T, Savas E, Savas MC. Genotype Distribution and 5'UTR Nucleotide Changes in Hepatitis C Virus. Balkan Med J. 2011;2011(3):232-6.

20. Gokahmetoglu S, Atalay MA, Kilınc A. Determination of the hepatitis C virus genotypes with'pyrosequencing'method. Erciyes Med J. 2011;33(2):99-102.

21. Kayman T, Karakukcu C, Karaman A, Gozutok F. Genotypic distribution of hepatitis $\mathrm{C}$ virus infection in Kayseri region. J Turk Mikrobiyol Soc. 2012;42:21-6.

22. Rota S, Fidan I, Lale Z, Kirisci O, Dede A, Cekic I. Determination of Hepatitis C Virüus Genotype in Turkey by PyroseQuencing Tecnology and its Associated with viral load and SGOT, SGPT Levels. Acta Medica Mediterranea. 2013;29:397-402.

23. Tezcan S, Ulger M, Aslan G, Yaras S, Altintas E, Sezgin O, et al. [Determination of hepatitis $C$ virus genotype distribution in Mersin province, Turkey]. Mikrobiyol Bul. 2013;47(2):332-8.

24. Saglik I, Mutlu D, Ongut G, Inan D, Ogunc D, Can Sarinoglu R, et al. [Distribution of hepatitis $C$ virus genotypes among patients with chronic hepatitis $\mathrm{C}$ infection in Akdeniz University Hospital, Antalya, Turkey: a five-year evaluation]. Mikrobiyol Bul. 2014;48(3):429-37.

25. Kalayci R, Altindis M, Gulamber G, Demirturk N, Akcan Y, Demirdal T. [Genotype distribution of chronic hepatitis B and hepatitis $C$ patients and investigation of the resistance patterns in hepatitis B cases]. Mikrobiyol Bul. 2010;44(2):237-43.
26. Denizli Probation Administration Dormitories . what is controlled freedom. 2013. Available from: http://www.denizli.adalet. gov.tr/denetim/denetim_serbest.html.

27. Roman F, Hawotte K, Struck D, Ternes AM, Servais JY, Arendt V, et al. Hepatitis $C$ virus genotypes distribution and transmission risk factors in Luxembourg from 1991 to 2006. World J Gastroenterol. 2008;14(8):1237-43.

28. Morice Y, Cantaloube JF, Beaucourt S, Barbotte L, De Gendt $\mathrm{S}$, Goncales FL, et al. Molecular epidemiology of hepatitis C virus subtype $3 \mathrm{a}$ in injecting drug users. J Med Virol. 2006; 78(10):1296-303.

29. Lole KS, Jha JA, Shrotri SP, Tandon BN, Prasad VG, Arankalle VA Comparison of hepatitis $\mathrm{C}$ virus genotyping by 5 ' noncoding region- and core-based reverse transcriptase PCR assay with sequencing and use of the assay for determining subtype distribution in India. J Clin Microbiol. 2003;41(11):5240-4.

30. Akkarathamrongsin S, Hacharoen P, Tangkijvanich P, Theamboonlers A, Tanaka Y, Mizokami M, et al. Molecular epidemiology and genetic history of hepatitis $C$ virus subtype 3a infection in Thailand. Intervirology. 2013;56(5):284-94.

31. Bourliere M, Barberin JM, Rotily M, Guagliardo V, Portal I, Lecomte L, et al. Epidemiological changes in hepatitis $C$ virus genotypes in France: evidence in intravenous drug users. J Viral Hepat. 2002;9(1):62-70.

32. Alfaresi MS. Prevalence of hepatitis $C$ virus (HCV) genotypes among positive UAE patients. Mol Biol Rep. 2011;38(4):2719-22.

33. Ahmad S, Salati SAA, Mattar EH, Al-Sabban AMH, Hamad AM. Epidemiology of Hepatitis C Virus (HCV) Infection. Physicians Academy. 2010;4(8):82-7.

34. Qazi MA, Fayyaz M, Chaudhary GMD, Jamil A, Malik AH, Gardezi AI, et al. Hepatitis C virus genotypes in Bahawalpur. Biomedica. 2006;22:51-4.

35. Ali S, Ali I, Azam S, Ahmad B. Frequency distribution of HCV genotypes among chronic hepatitis C patients of Khyber Pakhtunkhwa. Virol J. 2011;8:193.

36. Inamullah, Idrees M, Ahmed H, Sajid ul G, Ali M, Ali L, et al. Hepatitis $C$ virus genotypes circulating in district Swat of Khyber Pakhtoonkhaw, Pakistan. Virol J. 2011;8:16.

37. Kabir A, Alavian SM, Keyvani H. Distribution of hepatitis C virus genotypes in patients infected by different sources and its correlation with clinical and virological parameters: a preliminary study. Comp Hepatol. 2006;5:4.

38. Raja NS, Janjua KA. Epidemiology of hepatitis C virus infection in Pakistan. J Microbiol Immunol Infect. 2008;41(1):4-8.

39. Zhang Z, Yao Y, Wu W, Feng R, Wu Z, Cun W, et al. Hepatitis C vi rus genotype diversity among intravenous drug users in Yunnan Province, Southwestern China. PLoS One. 2013;8(12).

40. Sanders-Buell E, Rutvisuttinunt W, Todd CS, Nasir A, Bradfield A, Lei E, et al. Hepatitis C genotype distribution and homology among geographically disparate injecting drug users in Afghanistan. J Med Virol. 2013;85(7):1170-9. 